\title{
A Unified Theory of Monetary Dynamics
}

\author{
José Villacis ${ }^{\mathrm{a}^{*}}$ \\ a University San Pablo, Spain. \\ *Corresponding author's email address: villacis.fhm@ceu.es
}

\section{A R T I C LE IN F 0}

Received: 08-10-2015

Accepted: 13-02-2016

Available online: 25-04-2016

Keywords:

Circulation of money, income multiplier, bank money multiplier.

JEL Classification: E00.

(C) 2016 The Authors. This is an open access article under the terms of the Creative Commons Attribution License 4.0, which allows use, distribution and reproduction in any medium, provided the original work is properly cited.

DOI: http://dx.doi.org/10.18533/rss.v1i4.11

\begin{abstract}
A B S T R A C T
In the end, the only and eternal vocation of money is circulation. This circulation causes the contrary effect to income expansion, studied by the income velocity of circulation of money, by the income multiplier and by the bank money multiplier. These three issues are thought to belong to the same operation. Therefore, a unified money theory can be established.
\end{abstract}

A dynamic economy finances investments with the savings existing in the system but, the economy is simultaneously growing in real and nominal terms. Such growth in circulating capital is only possible through the creation of money in the economic system. In general terms, the system tends to finance growth with the spontaneous creation of money.

\subsection{Introduction}

The money created by the system is the monetary base and the money circulating is the monetary supply, which is bigger than the former because of the bank multiplier. Money circulation means - and it cannot mean anything else but the purchase of goods and financial assets. In the end, it will be the purchase of goods and services. If this elementary statement can be proven, it can be said that the monetary version of aggregate demand is the circulating money supply measured by the quantitative theory.

This is the second essential piece in macroeconomics because its understanding includes any dynamic monetary process. The quantitative theory took it further with the School of Cambridge that took this theory away from mechanicism, made it strong-willed and eventually developed it into the theory of money demand. The income multiplier was originated by Keynes. The multiplier is a sequence of purchases and sales of a monetary mass that is the money supply. The addition of these purchases is a part of aggregate demand. It does not include all the money supply neither is the entire aggregate demand, but it works with concepts and the strength of the money supply and concepts of aggregate demand. Both, the velocity and the multiplier are caused by the same phenomenon although they differ in size: money circulation.

The money multiplier explains how money is created: money supply, starting from the monetary base that starts to react. The multiplier would not exist if money did not circulate and that circulation is the shift of bank deposits among banks. Deposits circulate, since they are money, as operations of purchasing of goods and, therefore, they are operations of part of the aggregate demand. The money multiplier implies constant purchasing operations which in fact mean money circulation. Therefore, the money multiplier is explained by 
the velocity of money circulation, and more precisely of bank deposits. If the Government, or for instance autonomous consumption, spends the deposits, the income multiplier will appear. Although money creation may exist, this creation is not explained by the multiplier, since it does not exist, but it is a version of the quantitative theory.

The first essential piece in Macroeconomics is the identity savings equal investments. However, it is a static identity. The dynamic identity states that, once savings finance investments, the creation of goods, both for consumption and capital appears, then the way in which this financing takes place has to be explained. Savings are channelled towards investments. It is only possible to explain it with the creation of new money in the economic system allowing the finance this new production called circulating capital, where fixed assets in the hands of the producer are also included. It is possible to have this finance even without the creation of new money if savings circulate in such a way that it allows expansive effects higher than their initial magnitude.

In all these phenomena: the velocity of circulation of money, the income multiplier and the monetary multiplier money circulation is present as well as money circulation and the opposite creation and circulation of goods and services. In essence, these are dynamic facts where the effect, the creation of nominal income is higher than the initial cause that is an initial monetary mass. In the quantitative theory, it is money supply, in the income multiplier, it is the increase of autonomous demand and in the monetary multiplier, it is the monetary base.

The flow of money and the flow of goods can be found in the market. Those who offer goods are demanding goods and those who demand goods are offering money. The money supply is the free money that, as a flow, is offered to demand goods. It is always dynamic money that influences the circulating flow of the economic system. It is not all the money in the market but the one that is free. And, on the other hand, it is not only the money created but much more, because, in fact, its effects in purchases are higher to the initial magnitude of the money created. As far as the rotation of money is concerned, by means of any phenomenon: the income velocity, the income multiplier and the monetary multiplier, money supply is being mentioned. Money circulates according to the paradigms of income velocity, income multipliers and bank money. It is essential to understand that in these three cases the main issue is money supply.

From a different point of view, income, which is the result of the circulating impact of money supply, is money as a reflection of the production that has been created. It is income will be offered later as money supply in the dynamics of purchases. But it has to be wondered if all the money or, more precisely, all the money in circulation is monetary supply; in other words, if all the money supply is necessarily transformed into aggregate demand. A part of it demands financial assets in the financial system either in the Stock Exchange or in banks. Eventually, it seems that this money supply is liberated: What joins the system in the form of savings leaves it in the form of investment, making aggregate demand grow. This is the hypothesis of the financial expert as a simple bridge or pipe connecting savings and investment and investments are a part of aggregate demand.

Germán Bernácer proved the existence of net availabilities or third degree availabilities in his theory of the monetary market published in Spain in 1922. He claimed that if there is a part of savings trapped in the financial system in frantically speculative processes. There is also a part of savings going to investments, but not net availabilities that are savings not invested and not kept. The existence of net availabilities, originated as money supply and income reduce the existence of money supply in the market. They will therefore limit the possibilities of finance of nominal income in the three instances.

\subsection{The income velocity of money}

Nominal income $\mathrm{Y}$ is financed and created by the demand of goods and services expressed in the left hand side of the equation of the quantitative theory M.V.= Y. Money supply is the money that, once it has been created, starts to circulate in the system. Circulation or rotation means the frequency in simultaneous purchasing operations with operations of creation, supply and sale of the nominal production in the period. Several arguments can be shown about that monetary supply. The first is that it is wished or preferred as a periodical percentage of the total nominal income $(\mathrm{k}<1 ; \mathrm{M}=\mathrm{k} . \mathrm{Y})$. This is its essential goal. It can be said, then, that this amount of money is remarkably lower than nominal income $(\mathrm{M}<\mathrm{Y})$. By circulating, it makes nominal income possible. This explains a dynamic monetary phenomenon: a cause is lower in magnitude than its effect.

Secondly, it will demand from monetary institutions an amount of money necessary for these transactional targets $\mathrm{L}(\mathrm{i}, \mathrm{Y})$. In balance, this demand will equal supply or that percentage of nominal income $\mathrm{L}(\mathrm{i}, \mathrm{Y})=\mathrm{M}$; $\mathrm{L}$ $(\mathrm{i}, \mathrm{Y})=\mathrm{k} . \mathrm{Y}$. The third one is that this quantity of money will circulate in the system and such circulation that is money supply will be the origin of nominal income. 
The fact that money is preferred is a valuable statement by the School of Cambridge (Marshall, Pigou, Keynes) that relates the quantitative theory of money with income theories. If $\mathrm{k}$ is taken to the left hand side of the equation: $\mathrm{M} .1 / \mathrm{k}=\mathrm{Y}$. Therefore, $1 / \mathrm{k}$ is the velocity of circulation of monetary balances, and more precisely monetary supply.

The aggregate demand in the system is, therefore, a monetary mass offered $\mathrm{V}$ times. It is important and paradoxically irrelevant that this money supply is constituted by liquid balances or cash, or by deposits in current accounts or even saving deposits. It is also irrelevant if they are called under different names, for instance autonomous demand. These remarks will be interesting when considering the income multiplier and the monetary multiplier because both of them reflect the circulation of monetary supply a number of times.

\subsection{Income velocity and income multiplier}

The income multiplier explains how a cause is lower than the increase in income effects that it causes. $\Delta \mathrm{A} . \alpha=$ $\Delta \mathrm{Y}$. The meaning of every element in this operation will have to be studied. Firstly, it has to be stated that they are not total magnitudes but causes and effects of increases. Secondly, the final effect is the increase in nominal income. Thirdly and most important, it has to be clarified that it is autonomous demand, whatever this is.

If the name "autonomous demand" is left aside and its nature is understood, it can be seen that this autonomous demand is an operation of handing money in; more precisely, monetary supply, to buy goods. No one can buy but with money and this money is, by definition, monetary supply. The increase of autonomous demand is an increase of monetary supply in circulation that, with the logics of the multiplier, persists in its nature since it is money constantly offered. In the course of this offer, money supply becomes national income but it keeps its nature of money supply. But in the example of the multiplier, a restrictive hypothesis appears: It is the existence of savings that are not hypothetically invested but withdrawn from the circulation. Therefore, in the example, money supply and nominal income grow geometrically and in convergence.

Let's compare the formulae of income velocity with income multiplier. By working out the value of $\mathrm{V}$, on the one hand $\mathrm{V}=\mathrm{Y} / \mathrm{M}$ and, on the other, in the multiplier: $\alpha=\Delta \mathrm{Y} / \Delta \mathrm{A}$. In both instances, the numerator is national income and the denominator is money supply. These two concepts, national income and money supply are indispensable in this comparison. Its macroeconomic meaning cannot be but the money velocity of rotation, which is accepted in income velocity but would have to be explained in income multiplier. The problem in this comparison lies in the statement that the increase in autonomous demand is the inclusion in the flow of income circulation of an increase in money supply. Explained in simple terms, if it is true that autonomous demand is money supply, an increase in it would have the same effect. They will be the same, with a different name.

To demand, for whatever reason, is the fact of offering money in exchange for goods and, therefore, it is the same to call it money supply - that is money used to buy - as calling it demand. In consequence, the fraction $\Delta \mathrm{Y} / \Delta \mathrm{A}$, can be replaced by: $\alpha=\Delta \mathrm{Y} / \Delta \mathrm{M}$, because, as it has been explained: $\Delta \mathrm{A}=\Delta \mathrm{M}$.

Once this statement is accepted, the multiplier is the rate of circulation, or the rate of rotation, or the velocity of movement of the increase in monetary units to finance increases in income. This process explains how money moves to multiply income.

The quantitative theory is almost a tautology, an identity that is always true because the monetary value of what is bought is always the same as the monetary value of what is sold. The quantitative theory can be applied to the case of an increase in autonomous demand that sets in motion a series of successive purchases and sales. It would not be right to state that the quantitative theory, considered in this case in terms of increases $(\Delta \mathrm{M} . \mathrm{V}=$ $\Delta \mathrm{Y}$ ), is not accomplished because this effect theoretically affects the multiplier.

The income velocity of money and the income multiplier are identical phenomena. Both multiply and both finance higher income levels. But the fact that they are identical phenomena or identical operations does not mean that their magnitudes are equal. The income velocity is the result of a dynamic flow, which is income, multiplied by a monetary stock; and the multiplier is the result of multiplying increases, which is a pure number. On the other hand, the velocity is the opposite of the preference for liquidity $\mathrm{k}(\mathrm{v}=1 / \mathrm{k})$, and the multiplier is the opposite to marginal propensity to saving $(\alpha=1 / \mathrm{s})$. For both magnitudes to be equal, it is necessary that the preference for liquidity and the marginal propensity to saving are equal.

\subsection{Bank multiplier and income velocity}

When the monetary base or new money reaches the banking system, it moves from an account to another account, usually current accounts and, in the end, the creation of bank deposits higher than the initial quantity of 
money will take place: BM. $\theta=$ M. Increases can also be considered : $\Delta \mathrm{BM} \cdot \theta=\Delta \mathrm{M}$. The final effect, as in the previous examples, is higher than the cause: $\mathrm{M}>\mathrm{BM}$.

When the monetary base is introduced in the banking system, it is transformed into deposits and these are, by definition, money supply. Money supply is also money circulating in sales and purchases operations. Deposits are created in these operations, which is the equivalent to money creation.

For the circulation and importance of deposits in terms of money - let's assume it for the moment- payments must be made (eliminating bank's orders transfer operations ). Those payments for goods and services received for handing in deposits mean income generation in the system. There are two questions in this process: whether money has actually been created, and the reasons why this creation is not formulated if income is being generated in the system.

What is happening to monetary supply creation? To answer this question, accounting and business administration can be applied: The case of a holding of companies that does not receive any money for a period, but payments are made among the companies belonging to the holding. The bank accounts will constantly receive increases in their deposits coming from the companies and there will also be constant withdrawals. This is a similar example to the one quoted for the creation of bank money but the accountants in the group of companies (not the accountants of one company), will verify that the consolidated accounting state of the group has not increased its deposits in net terms. Money has only moved. They cannot either say that money has been created. If this experiment took place in the banking system of a country, then, macroeconomists will disagree with accountants because the former will claim that money has been created indeed. Who should be believed? Accountants or business economists must be relied on because they handle real facts. When deposits circulate, they do imply an increase in other bank's deposits where the payment is made. It is also true that it means a decrease in the paying bank's deposits and in net terms a net increase in the deposits in the system will not have taken place.

However, the existence of growth in money supply is thought-provoking and, to a certain extent little probable because there will have been a series of payments in the system, higher in monetary generating, higher in monetary value than the initial monetary base. Otherwise, how could payments have been made if they probably generate income and they are higher in monetary value to the value of the money exogenously created in the system? The last resort is the explanation of the creation of monetary supply. What is really happening is that a rotation in bank deposits among bank accounts or among banks is taking place. The money multiplier is a special version of the velocity of circulation of money, in this case, of bank money because it only refers to bank money, that is: bank deposits. Since deposits are money supply (not all the money supply are deposits), it can be stated that those deposits multiplied by the velocity of rotation of bank money explain the entire amount of payments, that are higher to the initial cause, which is the monetary base.

It cannot be claimed that this velocity has the same numeric value that the income velocity of money for two reasons: Firstly because the income velocity only takes into account the preference for liquidity (k) as a proportion of nominal income. The velocity of circulation of bank money includes money in cash held by the public in proportion to deposits $(\mathrm{e}=\mathrm{E} / \mathrm{D})$ and, besides, the proportion of bank reserves in relation to deposits $(\mathrm{r}$ $=\mathrm{R} / \mathrm{D})$. These two elements make the velocity of circulation different. Cash in the hands of the public and the existence of reserves mean that there is some money withdrawn from the banking circuit - in a gradual and convergent way in the case of reserves- and, therefore, circulating money supply decreases. But, even if it decreases, it will keep circulating and making possible to make a series of payments.

\subsection{Bank multiplier and income multiplier}

It does not require an important mental effort to imagine that the increase in autonomous demand, the autonomous consumption or public expenditure start to work in the bank system. The most probable thing is that it occurs. If this reality is accepted, two connected expansive phenomena would take place: on the one hand the money multiplier and, on the other, besides, the income multiplier. The economic science must work with Ockham's razor and avoid two terms for the same fact and more important, two phenomena for the same operation. The choice will be either working with the income multiplier or the bank multiplier but not with both at the same time.

Velocity income of money has been identified in chapter III with the income multiplier and its existence has not been denied. It has been said that the income multiplier is the velocity of circulation of money supply.

It has to be explained why and how the bank multiplier is a special case of income multiplication and not of money. Assuming that the State finaces an increase in public expenditure, that is to say an increase in 
autonomous demand by means of a loan to the issuing bank, this will create monetary base and transfer it to the public sector to make the first purchases. It is not difficult to suppose that these payments will be made through banks.

Initially, that increase in monetary base $(\triangle \mathrm{BM})$ would reach the Central Bank as property deposits from the public sector. When the public sector starts to spend that money, deposits are transferred as deposits from other principals in other banks.If it is assumed that the purchase of end products, that is, a part of nominal income is the reason of all payments made and they are shifts or movements of deposits, each shift will cause an increase in nominal income. As deposits keep moving, though their magnitudes are smaller and smaller, income keeps increasing, but also in smaller amounts. In the end, income will have been multiplied. This means that the income multiplier has developed. Monetary flows derived from payments to production factors are considered as income. This is different to the concept of monetary stock, as can be observed in the quantitative theory. Therefore, it can be stated that, in this example, money has not been created and the deposits have just rotated or circulated. However, income has actually multiplied and it can be explained with money rotation or by income multiplication.

Denying this statement is equivalent to the illusions of a monetary magician that makes the public believe that he has got a lot of money in his sleeve when, in fact, it is the same money coming out once and again. If it is believed that the monetary multiplier exists, then two multipliers would co-exist for the same autonomous demand (or monetary base): the money multiplier and the income multiplier. There would be a supermultiplication measured by $(\Delta B M . \theta) . \alpha=\Delta Y$, which is a scientific nonsense. Either one phenomenon or the other has to be chosen and it has been proven that the monetary multiplier does not exist but it is a special versión of the velocity of circulation of money.

It is a fact that monetary authorities create money and this new money circulates around the system. This new money circulates around the system as autonomous demand by means of the circulation of bank deposits. Circulation makes it possible that money becomes money supply. In this case, it is called money supply because it circulates as aggregate demand. This is where its name comes from. Aggregate demand is the same as money supply because they are the result of the same operation. In the case of the income multiplier, there were successive waves of money supply (they were smaller and smaller) or waves of consumer demand. It cannot be noticed if money has been created in a suppossedly consolidated balance sheet of the banking system of a country. It can be stated that it has shifted from an account to another one, which is, in the end what the income multiplier and the velocity of circulation of money explain in their own way.

It has been observed that $\Delta \mathrm{BM}$ caused constant increases in income by circulating a number of times. The addition of these increases is: $\Delta \mathrm{Y}$. The result of: $\Delta \mathrm{Y} / \Delta \mathrm{BM}$ would be the income multiplier, since $\Delta \mathrm{BM}$ is an increase in autonomous demand set to work. In the previous example, it has to be assumed that all payments that are shifts or rotations of deposits generate income.

Therefore $\Delta \mathrm{Y} / \Delta \mathrm{BM}=\alpha$, which is the same as: $\alpha . \Delta \mathrm{BM}=\Delta \mathrm{Y}$.

The left hand side of the equation shows the continuous operations of the demand o the total aggregate demand caused by the first impact of autonomous demand $\triangle \mathrm{BM}$. The right hand side is the increase in production and income. The demand spreads into the banking system, but it shows the particular characteristics of the banking system.

In the example of the income multiplier, nothing is explained about the institution environment where payments are made and it is taken for granted that it is paid in cash. The time cash money lasts, is the period when people get that money in exchange for production and then spend it. If these payments are made in the banking system, they are made with deposits and there will be a part of them reduced by the existence of the bank reserve ratio.

However, the bank multiplier's value- suppossing it exists- must not be equal to the income multiplier for the following reasons: Firstly, the multiplier connects a stock variable with a flow that is money supply whereas the income multiplier relates two increases. Secondly, in the example of the monetary multiplier, there are two factors involved : the reserve ratio $r$ and the cash ratio $e$ that make values change their magnitude.

This equation always measures operations carried out and, therefore, this equality shows that the monetary value of what is bought is the same as the monetary value of what is sold. The expansion of income in the form of deposits is possible in the case of payments creating income because any time that a shift in deposits takes place, there is also a generation of reciprocal production and sale. This operation also explains the quantitative theory. 


\section{0}

To the search of a unitary theory

Monetary dynamic effects that finance nominal income admit both the quantitative theory and the income multiplier, once the monetary multiplier has been eliminated. To achieve this unified monetary theory, some concepts must be clarified. Firstly, the time and monetary balance should be considered. It is claimed that, at a first stage, monetary balance requires that money demand should equal money supply $(\mathrm{L}(\mathrm{i}, \mathrm{Y})=\mathrm{M})$. This statement is unwise as far as money is concerned. If there is a demand for money, the balance will appear when such demand is met by the monetary base, that is the initial creation of money by monetary authorities to meet that demand.

Later, this monetary base will change into money supply when it circulates. Therefore, in the quantitative theory money supply could be substituted by the monetary base. If the existence of a bank multiplier (BM. $\Phi=$ M) was accepted, the quantitative theory would be as follows:(BM. $\Phi) . \mathrm{V}=\mathrm{Y}$.

This would imply double multiplying. It is better to work in monetary balance and on the quantitative theory considering the base rather than monetary supply. Secondly, the velocity of circulation of money is different if money is used in abstract or general terms, as the quantitative theory does, or in the specific case of bank deposits.

In the quantitative theory, alternative financial assets were liquidated and transformed into money, circulating $\mathrm{V}$ times. In the case of bank deposits ( from the hypothetical multiplier), the money that would start to circulate is the monetary base, and its velocity is different because its value is influenced by money in cash and the bank reserves. This velocity can be called V' and its value will approach or will be the same as the hypothetical bank multiplier. The complete quantitative theory would be as follows:

BM.V+ BM.V' $=B M\left(V+V^{\prime}\right)$

Working from the autonomous demand in the income multiplier, the first question to be answered is : where does the autonomous demand come from? Since it is money, an increase in autonomous demand is a net increase in the system of such demand. This means that, if this increase is not a net increase in autonomous consumption, for instance, it must come from a decrease in another section of the demand, so that it can be financed.

If this happens, there will not be a net increase in autonomous demand. The only way to achieve a net increase in autonomous demand is to finance it with new money. That is, with an increase in the monetary base. Two examples make this type of expansion possible: the finance of budgetary deficits with new money from the central bank or by an increase in net exports. In this case a fluid, unstoppable expansion in income takes place in the system. What is the first impact on income: the monetary base, the money supply or the autonomous demand? Or are they the same thing? The first impact is the monetary base that becomes money supply in the circulating process. But this money supply does not multiply by circulating. Income does multiply.

The income multiplier can be transformed by exchanging autonomous demand for monetary base. When this base is exchanged for goods - in the case of autonomous consumption, for instance- it becomes autonomous demand. Therefore, the income multiplier would be:

$\Delta$ BM. $\alpha=\Delta \mathrm{Y}$

$\alpha=\Delta \mathrm{Y} / \Delta \mathrm{BM}$

In the context of monetary balance, an increase in money demand will take place, with the increase in monetary base. On the contrary, there would be an increase in interests rates that would stop income expansion: $\Delta \mathrm{L}(\mathrm{i}, \mathrm{Y})=$ $\Delta \mathrm{BM}$.

As it has been observed, the multiplier will be expressed in the following terms: $\alpha=\Delta \mathrm{Y} / \Delta \mathrm{BM}$ and it shows the times that an increase in monetary base must circulate to finance increases in total income. The same effect takes place in the income multiplier as in the rotation of bank money, attributed to the multiplication of money supply. In both of them, the value of what is produced will be equal to the value of what has been sold, expressed by the quantitative theory. In these three cases, there will be a rotation of the quantity of money to finance increases in nominal income. This rotation makes it possible that an amount of money that must be the monetary base, could finance a higher nominal income level. This is the essential fact. 


\subsection{Net availabilities}

Savings derive from income and are channelled to investment throught the financial system. The financial system is understood as neutral, which means that its function is acting as a bridge between savings and investment. This is not true. The financial system distributes part of the savings and transfers them to investments. Another part of them is kept in a process of speculation. This money trapped are net availabilities: savings neither invested nor accumulated. This means that savings coming in do not equal savings coming out. The opposite is equally possible that savings coming out are higher than those invested. In general, there is a variation of not invested net savings rotating in a speculative process in the financial system.

This statement was made by Germán Bernácer (Alicante -Spain 1883-1965) in his paper entitled La Teoría de las Disponibilidades published in 1922. He explained that there were three types of demand or preferences for money: one for consumption activities and another one for production activities. These two types of demand provide availabilities for ephemeral transactional activities because they disappear in a very short time to meet consumption and production demands. Among them there is also that part of savings addressed to investments. But there is a third type of demand that provides net availabilities in a global sense: the speculative demand.These are net availabilities or third degree availabilities. They are not invested savings and rotate in the finacial market.They are long-lasting by their own nature.

If there are net availabilities, the identity savings - investment is not accomplished in its financial sense. Consequently, restrictions should be made to the quantitative theory and the income multiplication and, above all, find out the velocity of circulation of net availabilities in the financial market.

\section{A. The Essential Static Equation}

The essential equation in macroeconomics saying that savings equal investment is altered once net availabilities have been discovered as a new type of income. On the other hand, the following statements will be understood better, once the concept of investment is understood. The fact of investing is the purchase of capital equipment and the finance of such equipment. Therefore, investments are not the production of capital equipment or the increase in capital by companies.

Production is an activity and demand- of capital, in this case- is another one. If the system produces capital equipment, it will be circulating capital in the same way as the flour for the miller, unless the contrary be proved. It is fixed assets when that production is demanded by companies that are going to use it. This is why business economists and accountants call it fixed and noncurrent material assets. It is circulating capital until it is demanded.

Availabilities come from income, and fixed capital is a part of production. This approach will question the functional identity between savings and investment. Production requires the presence of production factors that receive monetary revenues, including benefits, and their addition is the national income. As a consequence, the monetary value of production equals the monetary value of national income. It is a fact that savings finance investment but, if net availabilities exist as savings not capitalized, investments in that part will not take place. As a consequence, investments will be lower than savings. The essential equation in macroeconomics should be expressed in the following way:

Production $=$ production of goods for consumption + capital goods production .

Production $=$ Income

Therefore, income must be:

Income $=$ Consumption + Investment + Availabilities

Then:

Savings $=$ Investment + Availabilities

It can also be said that:

Availabilities $=$ Income - investment in consumption.

This equality expreses that availabilities are the part of income that remains free after having met consumption and investment expenditures. This fraction of income is allocated to speculation in the Stock Market and is not used for consumption or investment while doing so. 
Availabilities in the non-neutral financial system should be underlined. A person that receives a salary may buy a bond in the Stock Exchange and the one who sells it will invest those savings in the primary market in the case of a company. Or may buy a shirt with that money if the one who sells it is a speculator. In both cases, the financial market is neutral because it acts as a mere bridge.

This is not the case if a flow of savings goes from some hands to others, all of them in the financial market. In that case, savings coming from production and income do not go back to that circuit in net terms.

It can be wondered why in times of expansion in production and income, expansion takes place in Stock Markets as well. It is because the increase in income makes consumption and savings increase and, therefore, availabilities in net terms. It is also due to the fact that availabilities have their own money velocity in the nonneutral financial system. If the nominal value of assets subject to speculation is $\mathrm{AF}$ and $\mathrm{M}$ is the money supply involved in these transactions, the velocity of speculative circulation will be:

$\mathrm{V}_{\mathrm{f}}=\mathrm{AF} / \mathrm{M}$

The components of this velocity, with a different value to income velocity of money, are basically subjective and monetary and their causes are different to income velocity.

\section{B. The Essential Dynamic Equation}

In the identity savings equal investment, a single period is considered or perhaps two between which nothing happens. The truth is that between the two periods some events take place: increases in production, production financing, income generation (and savings). A dynamic equation is necessary relating savings and investment.

Let's assume, for the sake of the analysis, that there are no net availabilities and the financial system is neutral. In that period, income, originated in production demands it in two ways: by demanding consumer goods and by demanding capital goods, that is, by means of investing itself. It is a fact that in that period companies are creating products applying fixed and variable production factors. The fact is that new production in the period, including fixed capital, is circulating capital.

The problem raised is if savings in that period are devoted to investments or to the purchase of capital equipment for the previous production, where do monetary means are obtained from, to finance circulating capital? The answer is the creation of money. Otherwise, that new production or circulating capital would never exist. The conclusion that this dynamic balance exists can be reached by studying a situation of unbalance. A situation of unbalance can appear in the case when savings in the period are used to finance new production. In this situation, there would be two flows in production: one of them would be the new production and the other one is the capital equipment created that is no longer demanded. By generating new production, there would be only one level of income (equal to the previous production) but two flows of supply. Therefore, supply would abound, fed by two sources, and a single demand, unable to absorb it, would cause the depression.

Once this hipothetical situation of unbalance has been studied, it will be agreed that the creation of money will be necessary to finance the new production, generate new income and setting savings free to demand new production from capital equipment. The formula of dynamic identity is:

Savings + New Money $=$ Investment + New Production

A second issue can be raised: How much money is needed to create that new production in a situation of balance. The answer is an amount of money that, by circulating, can generate new production if that production is enough and does not exceed the needs. It would be : $\Delta \mathrm{BM} . \mathrm{V}=\Delta \mathrm{Y}$.

It has been observed, in chapter IV that savings in the system, going from an account to another in the form of deposits, circulate a number of times that make it possible to achieve a higher income level. It means that : $\Delta \mathrm{S}^{\prime} \mathrm{V}^{\prime}$ $=\Delta \mathrm{Y}$, and it has been observed that $\Delta \mathrm{S}<\Delta \mathrm{Y}$. This rotation in saving deposits would spontaneously finance a higher income level. Therefore, the financial capacity of savings in the system would be their own value plus the financial capacity of savings derived from its velocity: : $\mathrm{S}\left(1+\mathrm{V}^{\prime}\right)$.

The new produciton in the period can be helped by the new money created in the system, by its velocity or by savings multiplied by their velocity or both simultaneously:

$\Delta$ BM. $\mathrm{V}+\Delta \mathrm{S}\left(1+\mathrm{V}^{\prime}\right)=$ Investments + Circulating Capital. 
It can be concluded that :

$\Delta \mathrm{BM} . \mathrm{V}+\Delta \mathrm{SV}^{\prime}=$ Circulating Capital

The circulating capital is supported by the new money and, besides, by the rotation of saving deposits. Therefore, it is does not need to finance investments. There are two flows of income. One of them is generated by investments and the other one by the creation of circulating capital or new production that can be absorbed by the two production flows offered: one of them of capital equipment of the previous production plus the production of the period's production or circulating capital.

The economic system tends to generate a current of financing of circulating capital. This trend comes from the internal stress caused by the need of growth. There are two types of such trends: exogenous and endogenous. The former raise from the pressures of businessmen to banks, transmitted to monetary authorities to create money. The latter are caused by the pressure of companies among themselves and on banks, gen erating two effects: an increase in rotation of bank deposits on the one hand and, on the other, the creation of quasimoney. In general, they will cause the monetary base and the rotation of bank deposits that will help finance circulating capital. Finally, in case of monetary restriction, businessmen issue quasimoney serving as money. That money, that is the same as the rest in the banking system, rotates to make monetary growth possible. It usually grows in relation to monetary restriction an is, therefore, more expensive.

In this case, there is money creation and it does rotate. It should be then multiplied by its own circulation in the banking system. Summing up, the creation of money is needed to create new production, which is the addition of circulating capital of companies. Otherwise, to finance new production, money must rotate in the banking system. These devices are caused from the outside, from the bank creating the monetary base or else from the stress among companies or between them as a whole and the banking system. This causes the rotation of bank deposits of companies and the creation of quasimoney, different in nature to the multiplication of money supply.

\section{The quantity of money.}

It is necessary to specify the quantity of money needed to finace the growth in production in balanced dynamic economies. A sequence of intermediate goods and final goods is simultaneously generated in dynamic economies. The addition of added values of intermediated goods is the value of the end product. It is an elementary rule that the value of intermediate goods cannot be added to the value of the end product. But this statement cannot be mistaken with the payments that must be made in the system.

These payments are made by buyers whatever the role they have in production. Consumers will make payments for the prize of the end production and intermediate producers (all producers) will pay sellers. This statement means that there will be two different types of payments: one of them is the monetary value of final production and others will be the addtition of all payments of all intermediate productions. The addition of all will be the total addition of payments made in the period. This must not lead to the conclusion that the total of all these payments is the value of the production in the period. Circulating capital must be divided into two types to understand these payments or the finance of these two categories of payments.

There are two types of circulating capital: first class circulating capital and second class circulating capital. Let's assume that the addition of added values: $a b+b c+c d+d e+e f+f g+g h=a h$. The one belonging to the first class is the finished end production and consumers and companies pay it when they withdraw them from the market. These are the first payments.

The total circulating capital (neither the first, nor the second class one) is the addition of all added capitals in all the stages in production, simultaneously produced. This means that in a period, companies are producing at the same time $a b+a c+a d+a e+a f+a g+a h=L$. This is different to the mere addition of added values. The fact that farmers give their wheat to the mills and then it is sent to the bakers does not mean that, at the same time, no more wheat is being produced, nor sent to the miller and bakers do not produce any more bread. The second class circulating capital is the difference between the total circulating capital L and first class circulating capital: $\mathrm{L}-\mathrm{ah}$. This second class circulating capital increases at the same time as the stages in the transformation of the product and its existence is ephemeral because it lasts since production starts until the end product is sold. It must be stressed that the fact that the end product production is the addition of the added values and it is called first class circulating capital, coexisting with second class circulating capital being generated by the economic system: all added values, all of them originated in the same period. 
It is true that payments are made with money to acquire the end production, but it is also true that payments are constantly being made among entrepreneurs to pay for second class circulating capital. But it has to be known how much money needs to be created or how much money should circulate in the system. Once savings exists, the demand is weakened by the first and second class circulating capital produced. The demand is recovered by investments in these savings of first class circulating capital that, afterwards, when it is incorporated to companies, becomes fixed capital. But the money needed is the one used to finance second class circulating capital because companies need it to keep creating new production. The first class circulating capital has already been financed with money from previous periods and the payment to production factors that has been made with money makes demand possible as well as the balance in markets and the static possibility that savings would equal investments.

In a dynamic sense, payments are being made that require new money. They pay for all the added value throughtout all stages except for the first class circulating capital that is the end production. Payments among companies are mostly made through bank deposit movements and through the generation of quasimoney. In this sense, the essential identity can be dynamically formulated by explaining how savings plus new money equal investments plus circulating capital. One of these essential points is the statement that in the needs of payment among companies, basically used to finance payments among them, the second class circulating capital helps savings to accelerate its circulation, favouring higher payments. These needs to make payments can also be transmitted to private banks and, then, to the Central Bank or issuing bank to create monetary base.

\subsection{Conclusion}

Money makes nominal income generation possible by circulating in the opposite direction to goods. This monetary phenomenon is possible with the analysis of the velocity of circulation of money, which is disguised of three supposed paradigms: income multiplication, the creation of bank money and the velocity of circulation of money itself. The first thing to be done methodologically is to define money supply and find out the existing differences with the monetary base. The latter is money that has been created and becomes money supply when it is offered in exchange for goods. In the income velocity the monetary mass circulating is the money supply. In the income multiplier, money that starts to circulate is the money supply, the first impact, although it is known as increase in autonomous demand. The relationship between the increase of the end nominal income, which is the effect, and the increase of money supply, that is the cause, is the income multiplier. Therefore, the result of the operation between increases expresses the times that units of money supply circulate to finance end increases in nominal income.

The monetary multiplier multiplies the monetary base and the result is the creation of banking money or money supply. What is happening in fact is that bank deposits circulate among acounts, usually current accounts. As it makes higher payments possiblethan the monetary base, it seems that money has been created. It is just appearance. It is actually a special case of monetary circulation, more precisely of bank deposits.

In a dynamic context of time and creation of goods, the identity savings-investments is altered. While savings finace investments in the period, new money must be created to finance new production that, in the hands of entrepreneurs, will become circulating capital. This new production is helped both by the creation of new money and the rotation of savings, that is by savings multiplied by their velocity of rotation. The introduction of net availabilities, that is savings neither invested nor accumulated circulating in the financial market complete and finishes off the essential equation.

Suggestion for Future Research: multiplier, velocity of circulation, monetary base, saving circulate.

\section{References}

A Competitive Theory of Fluctuations and the Feseability and Desirability of Stabilization Policy, en Rational Expectations, Adjusment,and the Dynamic Respnse of Income to Policy Changes (1973), Journal of Money,Credit and Banking,4 (February),157-172.

An Equilibrium Model of the Business Cycle (1975), Journal of Policitical Economy, 83:113-44.

A Teatrise on Money (1930) (London and New York:Mc Millan).

A Tract on Monetary Reform (1923) (London Mc:Millan).

Abel, Andrew B. 198: Empirical Invesment Equations:An Integrativa Framework, in On the State of Macroeconomics.Número 12.Amsterdam:North Holland.

Are Market Forecast Rational? (1981), American Economic Review,71:293-306.

Azariadis,C. 1975 : A Reexamination of Natural Rate Theory , American Economic Review, 71: 946-60. 
Barro, Robert J. 1977 : Unanticipated Money Growth and Unemployment in the United States, American Economic Review, 67: 101-15.

Barro, Robert. 1980: A Capital Market in an Equilibrium with Restricted Borrowing. Econometrica, 48: 1393417. http://dx.doi.org/10.2307/1912814

Barro,Robert 1980: Federal Deficit Policy and the Effects of Public Debt Shocks, Journal of Money, Credit and Banking, 12; 747-62.

Bernácer Germán : 1916. Sociedad y Felicidad. Edit.Beltrán. Madrid (Books)

Bernácer Germán: 1922. La Teoría de las Disponibilidades. Madrid.Barcelona.(Article).

Bernácer Germán:1925 El Interés del Capital. Edit.Lucentum.Alicante.(Books).

Bernácer Germán: 1945.La Doctrina Funcional del Dinero. Edit.Consejo Superior de Investigaciones Científicas.Madrid (Books)

Brunner, K. and Meltzer. A., Carnegie-Rochester Conference Series in Public Policy.Amsterdam:North Holland.

Blinder, Alan 1979 Economic Policy And the Great Stagflation, New York Academic Press.

Blinder,Alan S.,y Fisher. 1981:Inventories, Rational Expectations, and the Business Cycle, Journal of Monetary Economics, 8: 277-304. http://dx.doi.org/10.1016/0304-3932(81)90012-X

Baumol William 1952. The Transaction Demand for Cash:An Inventory Theoritic Approach. Quaterly Journal of Economics, 66 November.

Baumol William, James Tobin, 1956. The Interest Elasticity of Transactions Demand for Cash. Review of Economic and Statistics,August.

Cagan, Phillips, 1956 The Monetary Dinamics of Hiperinflation, en Studies in the Quantity Theory of Money, editado por Milton Friedman.Chicago:University of Chicago Press.

Econometric Policy evaluation: A Critique(1976), in The Phillips Curve and Labor Markets, edited by Karl Brunner y Allan Meltzer.Amsterdam:North Holland.

Expectation and Economic Policy, (1980) editado por Stanley Fisher. Chicago:Chicago:National Bureau of Economic Research.

Feldstein Martin, 1980: Comments on A Competitive Theory of Fluctuations and the Feastibility and Desirability of stabilization Policy, En Rational Expectations of the Gramlih Study, Brooking Papers on Economic Activity,1: 167-168.

Feige,E. 1964: The Demand for Liquid Assets:A Temporal Cross-Section Analysis (Englewood Cliffs,N.J.:PrenticeHall)

Fisher,I. 1911: Purchasing Power of Money (New York:Mc Millan)

Friedman M. 1956:The Quantity Theory of Money;A Restatement, en M.Friedman (Edi.) Studies in the Quantity Theory of Money (Chicago:University of Chicago Press).

Friedman M. 1957: A Theory of the Consumption Function (Princeton,N.J.:Princeton Univeristy Press for the NBER).

Friedman M. Interest. 1966: Rates and the Demand for Money, Journal of Law and Economics, 9.

Friedman M. 1968: The Role of Monetary Policy,American Economic Review, 58:1-17.

Grossman,S., y Joseph E.Stiglitz.1981: Information and Competitive Stock Prices,American Economic Review,66 246-53.

Hall, Robert E.1976: The Phillips Curvew and Macroeconomic Policy., in the Phillips Curves and Labor Markets,editado por Karl Brunner y allan H.Meltzer. Carnegie-Rochester Conference Series on Public Policy number 1.Amsterdam:North Holland.

Hayek,F.A. 1945: The Use of Knowledge in Society, American Economic Review, 35: 519-30.

Hicks, J.R. 1935: A Suggestion for Symplifying the Theory of Money. Economica, 2 (February).

Kearl, James.1979: Inflation, Mortgagges,Houssing, Journal of Political Economy, 87: 1115-38. http://dx.doi.org/10.1086/260815

Keynes,J.M. 1936 : The General Theory of Employment, Interest and Money. New York:Harcourt,Grace and World.

Klein,B. 1974: The Competitive Supply of Money ,Journal of Money,Credit and Banking, 6(November), $423-454$. http://dx.doi.org/10.2307/1991457

Kuhn, Thomas S.1970: The Structure of Scientific Revolutions., 2nd Edition.Chicago:University of Chicago Press.

Kydland,Finn E., y Edward C.Prescott.1977: Rules Rather than Discretion: The Inconsistency of Optimal Plans, Journal of Political Economy, 85: 473-91. http://dx.doi.org/10.1086/260580

La Oferta Agregada como Función de la Demanda Agregada Permanente (1992), In Revista de Derecho Financiero y de Hacienda Pública. Volumen XLII-Número 219 (May-June).Madrid.

La Política Fiscal No Existe (1990), In Revista de Derecho Financiero y Hacienda Pública. Volumen XL-Number 205 (January-February).Madrid.

Laidler, D.1966,: Some Evidence of the Demand for Money, Journal of Political Economy,74 (February),55-68. http://dx.doi.org/10.1086/259109

Lintner, John.1965: The Valuation of Risk Assets and the Selection of Risky Invesment in Stocks Portfolios and Capital Budgets, Review of Economic and Statistic, 47:13-37. http://dx.doi.org/10.2307/1924119 
Lucas, Robert E. Pr. 1972: Expectations and the Neutrality of Money, Journal of Economic Theory, 4:103-24. http://dx.doi.org/10.1016/0022-0531(72)90142-1

Lucas,R.E. Jr. y T.....Sargent.1978:After Keynesian Macroeconomics, in After the Phillips Curve:Persistence of High Inflation and High Unemployment. Federal Reserve Bank of Boston Conference, vol. 19,Boston:Federal Reserve Bank, pp.49-72.

McCallum,Bennet T. 1976: Rational Expectations and the Natural Rate Hypothesis: Some Consistent Estimates, Econometrica, 44:43-52. http://dx.doi.org/10.2307/1911379

Matthews,R.C.0.1963: Expenditure Plans and the Uncertainty Motive for Holding Money, Journal of Policital Economy,71(June),201-218. http://dx.doi.org/10.1086/258767

Mayer, Thomas.1978: The Structure of Monetarism. New York:Norton.

Meltzer,Allan.1978: Monetarism,Keynesian and Quantity Theories, in The Structure on Monetarism,editado por Thomas Mayer.New York:Norton.

Methods and Problem in Business Cycles Theory (1980), Journal of Money,Credit and Banking, 12: 696-715. http://dx.doi.org/10.2307/1992030

Meyer,P.A. y Neri,J.A.1975: A Keynes-Friedman Money Demand Function,American Economic Review,65(September),610-623.

Mishkin,Frederik S. 1978: Efficient- Market Theory:Implications for Monetary Policy, in Brookings Paper on Economy Activity,editado for Okun y G.L.Perry.Vol.3,pp 707-68

Modigliani, F.Brumberg,R.E. 1954: Utility analysis and the Consumption Funtion:An Interpretation of CrossSection Data, en K.K.Kurihara, Pos-Keynesian Economics,Londres,George Allen\&Unwin.

Monetary Policy and Long Term Interest Rates: And Efficient Market Approach (1981), Journal of Monetary Economics, 7:29-55. http://dx.doi.org/10.1016/0304-3932(81)90050-7

Musgrave,R..A. 1939.: The Voluntary Exchange Theory of Public Economy, en Quaterly Journal Economy.

Muth, John F. 1960: Optimal Properties of Exponencially Weithted Forescast, Journal of the American Statistical Association,55: 299-306. http://dx.doi.org/10.1080/01621459.1960.10482064

Nelson,C.R. y G.W.Schwartz.1977: On Testing Hypothesis That the Real Rate of Interest Is Constant, American Economic Review,67: 478-86.

Okun, A. M. 1981: Prices and Quantities. Washington D.C.:The Brooking Institution.

Phelps, Edmund S. 1970: The New Microeconomics in Employment and Inflation Theory,edition by Phelps.New York: Norton

Phillips,A.W. 1958: The Relation Between Unemployment and the Rate Of Change of Money Wage Rates in the United Kindgdom, 1861-1957, Economica,25: 283-94. http://dx.doi.org/10.2307/2550759

Prescott, Edward C. 1977: Should Control Theory Be Used for Economics Stabilization? , in Optimal Policies,Control Theory and Technology Exports, editado por Karl Brunner y Allan Meltzer. CarnegieRochester Conference Series on Public Policy.Amsterdam: North Holland. http://dx.doi.org/10.1016/01672231(77)90022-7

Radner, Roy 1979: Rational Expectations Equilibrium: Generic Existence and the Information Revealed by Price, Econometrica, 47:655-78.

Rational Expectations an the Theory of Price Movements (1961), Econometrica, 29:315-35.

Rational Expectations and Macoeconomics Stabilization Policy (1980), Journal of Money,Credit and Banking,12: 716-46. http://dx.doi.org/10.2307/1992031

Rules, discretion and the Roles of the Economic Advisor, in Rational Expectation and Economic Policy (1980), editado por Stanley Fisher.Chicago:National Bureau of Economic research.

Sargent,Thomas J.1976: The Observational Equivalence of Natural and Unnatural Rate Theories of Macroeconomics, Journal of Political Economy, 84: 631-40. http://dx.doi.org/10.1086/260465

Sargent, Thomas and Neil Wallace.1975: Rational Expectations, the Optimal Monetary Instrument and the Optimal Money Supply Rule, Journal of Polical Economy,83:241-54. http://dx.doi.org/10.1086/260321

Sheffrin,Steven M.1979:Uninticipated Money Growth and Duput Fluctuations, Economic Inquiry,17: 1-13.-1983. Rational Expectations. Cambridge University Press, Cambridge,England.

Some International Evidence on Ouput-Inflation Trade-offs (1973), American Economic Review,: 326-34.

The Monetarist Counter-Revolution Today-An Appraisal (1981), Economic Journal,91: 29-42. http://dx.doi.org/10.2307/2231692

The Permanent Income Concept in a Macroeconomic Model (1968) Oxford Economic Paper, 20 March,11-23.

The Theory of Public Finance (1959), Londres,McGraw-Hill.

Tobin, James, 1966: Money and Economic Growth, Economterica, 33:671-84. http://dx.doi.org/10.2307/1910352 Undesttanding Business Cycles (1973), in Stabilization of the Domestic and International Economy,editado por Unemployment Policy (1973), American. Economy Review, 68: 353-7

Villacís, José. 1987: Política Monetaria y Fiscal: Una Paradoja de los Subrogados del Dinero. In Revista de Derecho Financiero y de Hacienda Pública. Volumen XXXVII, number 191 (September-October).Madrid. 